\title{
Congregational Discernment and LGBTQ+ Inclusion: Process Lessons from 21 Congregations
}

\author{
Helen Harris * (D), Gaynor I. Yancey, Kimberly Dawson and Jess Gregory \\ Diana R. Garland School of Social Work, Baylor University, Waco, TX 76798, USA; \\ Gaynor_Yancey@baylor.edu (G.I.Y.); Kimberly_Dawson@baylor.edu (K.D.); Jess_Gregory2@baylor.edu (J.G.) \\ * Correspondence: Helen_Harris@baylor.edu
}

check for

updates

Citation: Harris, Helen, Gaynor I

Yancey, Kimberly Dawson,

and Jess Gregory. 2021.

Congregational Discernment and LGBTQ+ Inclusion: Process Lessons from 21 Congregations. Religions 12: 25. https://doi.org/10.3390/ rel12010025

Received: 3 December 2020 Accepted: 28 December 2020 Published: 31 December 2020

Publisher's Note: MDPI stays neutral with regard to jurisdictional clai$\mathrm{ms}$ in published maps and institutional affiliations.

Copyright: $(\odot 2020$ by the authors. Licensee MDPI, Basel, Switzerland. This article is an open access article distributed under the terms and conditions of the Creative Commons Attribution (CC BY) license (https:// creativecommons.org/licenses/by/ $4.0 /)$.

\begin{abstract}
The question of LGBTQ+ inclusion in churches is rapidly becoming an open conversation in congregations and denominations seeking answers in policy and practice. As society is engaging the question of LGBTQ+ rights in the courts, denominations are addressing LGBTQ+ inclusion, and as increasing numbers of LGBTQ+ Christians come out in their faith communities, church members and their churches, with their religious structures, are called on to take positions, often in the absence of agreement. In background research and 97 interviews with leaders and members of 21 congregations in three denominations, a research team discovered processes, models for conversation, and resources to address the risks of division and changes in membership and finances. In the following article, the authors include findings and resources from congregations, process models, and suggestions and possibilities for families of faith considering how to move forward in addressing one of the more pressing and divisive issues in the church.
\end{abstract}

Keywords: LGBTQ+; churches; denominations; discernment; models; processes

\section{Introduction}

Persons who identify as Christian and as LGBTQ+ often experience marginalization in the churches in which they grew up and in the denominations in which they may feel called to serve (Baldock 2014; Cole and Harris 2017; Gold 2008; Harris et al. 2020; Robertson 2017). As culture in the United States shifts with increasing focus on legal equality and rights for LGBTQ+ persons, there are changes in the law, such as the marriage equality decision by the Supreme Court of the United States (Chu 2020; SCOTUS 2014). At the same time, more LGBTQ+ persons are open about who they are. That is true in congregations as well, especially as some denominations and congregations have been engaging in the conversation since the 1990s, at larger rates over the past 25 years (Gaede 1998; Polaski et al. 2013). Persons who identify as Christian and as LGBTQ+ are increasingly visible in the culture and in churches. Denominations and congregations have both the challenge and the opportunity to address questions of membership, leadership, and participation in sacraments like marriage and the blessing of children. There are models emerging to guide the conversations, but few are specifically for congregations. This article explores the discernment experiences and recommendations of 97 participants in 21 congregations and 3 denominations.

A review of the literature clarifies the context of the research. The history of the Christian faith began with hope and joy and with questions of inclusion. The development of the Christian church includes both times of significant positive impact, growth, and new hope for a hurting world. At the same time, there is ongoing disagreement, division, and fracturing over understandings of scripture, policy, and positions. We examine here the literature informing our study: history of the early church, policy, and LGBTQ+ history in the Baptist, Methodist, and Presbyterian denominations. The church has impacted, and been impacted by, social issues and change. The specific issue of sexual orientation and 
sexual identity and the church is only one controversial topic that the church has wrestled with through the years.

\subsection{The Christian Church}

The crucifixion of Jesus of Nazareth was at the intersection of religion and politics as the leadership of the Jewish faith conspired with the political power of Rome to use force to direct the beliefs and practices of the people (Shelley 2013). The early church began hidden underground and in hiding but grew in numbers and open expression first in Jerusalem and then across the Middle East and to the known world (Richards 2020). As the faith movement of the early Christian church grew, questions of inclusion of Gentiles, questions of leadership of disciples only and men only, questions of property ownership, and allegiances were all sources of difference. The role of women was addressed differently in different parts of the world as cultural influences over church structures and worship structures developed (Garland and Garland 2007). New Testament authors wrote about their experiences, and those letters began to have influence on church policy as they addressed the very questions that were being raised in new churches and communities of believers (Richards 2002). Today, there are disagreements about whether those letters were to be understood in the cultural contexts that produced them or are to be understood as universally true. Another issue is who is "empowered" to provide analysis or interpretation of those letters/scriptures. In the Catholic church, for example, the authority is the Pope and, by extension, bishops and priests who are trained and dedicated to the work of the church. In some denominations, that role belongs to leaders in the church who are trained in church doctrine or who by declaration are called by God to interpret God's word (Richards 2020). In some denominations, the doctrine of "priesthood of the believers" ascribes to all persons of faith the right and responsibility to read and interpret and apply the scripture in their lives. In most denominational groups, there is a mix of response to the teaching of leaders and personal interpretation. The role of leaders in interpreting the scripture increases the power differential and the cultural understandings when leaders are primarily one group in society-notably, in America, white heterosexual cisgender males (Baldock 2014).

\subsection{The Church, Social Issues, and Change}

There are hundreds of religious groups in the United States, including a plethora of denominational groups with a wide variety of policy and organizational structures. One important structure to this study was the relationship of denomination to congregation concerning decision making, policy, and living that out in an increasingly diverse country and society. Denominations are not new to the controversies of social justice issues. In the United States, the history of the church with slavery and racism is one example that most denominations wrestled with and continue to struggle with today as "the 11 a.m. hour on Sunday is the most segregated hour of the week" (King n.d.). This is true across most major denominations, including those with formal structures and those with a greater focus on the local church structure.

\subsubsection{Social Issues Then and Now}

Northern and southern Baptists split in the mid- to late 1800s in response to the support of northern Baptists for abolition and for the Union and the provision of southern Baptists of a denomination of Baptists supportive of the economic system of slavery and of the Confederacy (Tisby 2019). This was true of Methodists and Presbyterians as well. Tisby (2019) states: "The three of the most influential denominations at the time-Methodists, Baptists, and Presbyterians-all divided and fought over whether Christians could own slaves and remain in good standing" (p. 76). 


\subsubsection{Baptist}

Baptist history in the Americas began in the 17th Century with Baptists migrating from England to find religious freedom. The small denomination found both in the north and south experienced significant growth in the 1700s. Baptist associations were formed to increase fellowship and solve common problems together. The consistent concerns of autonomy and freedom became a significant problem over the issue of slavery and related economics (Baker 2020, para. 1-4; Jones 2020). The Southern Baptist Convention (SBC) was created in 1845 in response to disagreements over slavery and grew in strength (Jones 2020; Tisby 2019). The SBC was described by Jones (2020) as having "sacralized white supremacy" and grew into "the single largest Christian denomination in the country" (p. 2). In 2016, the SBC "voted to repudiate the Confederate flag" and has since apologized for racism (Zylstra 2016, para. 1).

Levy (2014) identified the positions of four of the many Baptist denominations with a range of LGBTQ+ inclusion and a range of hierarchical structures. The Association of Welcoming and Affirming Baptists (group rather than denomination) assumes inclusion in the church. Both the National Baptist Convention (NBC) and the Southern Baptist Convention (SBC) espouse autonomy of the local church. The NBC says little about local church positions. The SBC passed a resolution "requiring Southern Baptist churches to oppose same-sex unions" (Levy 2014, p. 14). Affiliation with the SBC and some other Baptist denominations requires fidelity to denominational position(s).

The position of the SBC on matters of LGBTQ+ inclusion continues to be a traditionalist position (Harris et al. 2020; Human Rights Campaign 2020, para. 1-4). This includes the positions of seeing LGBTQ+ persons' relationships as immoral, marriage and sexual relationships between a man and a woman, and "homosexuality" as sin requiring redemption (Harris et al. 2020; Human Rights Campaign 2020, para. 1-4). As a result, denominational affiliation with the SBC is not permitted for churches with affirming doctrinal positions, and a resolution in 2019 recommends that "believers who identify as gay or for whom sexual attraction includes persons of the same sex not use the terminology gay Christian as their identification" (Allen 2019; Harris et al. 2020).

\subsubsection{Methodist}

The United Methodist Church (UMC) has had mixed responses and denominational messages with respect to social issues including Gentiles, slavery, and LGBTQ+ inclusion (Fishburn 2003; Levy 2014; McConkey 2018). McConkey (2018) noted that minister John Wesley was opposed to slavery and that the denomination was divided over the issues of slavery and other social justice issues. Fishburn (2003) noted that the denomination divided over slavery in the mid-1800s. Over time, Traditionalists prioritized "personal piety", while Progressives emphasized social justice (McConkey 2018, pp. 52-53). The author identified the importance of tradition in the United Methodist Church and the assessment that "over the first 1900 years of Church history, homosexual behavior has been decidedly condemned" (p. 45). Duggins (2018) reported on the inevitable differences between Traditionalists and Progressives in the Methodist church over the issue of LGBTQ+ inclusion and ordination, the deep and challenging differences, and the congregation's process attempting to find a "Way Forward" (p. xix).

The official position of the denomination is determined by the General Conference and articulated in the Book of Discipline (p. 10). In recent years, the General Conference studied the matter of LGBTQ+ inclusion, came up with three alternative positions, and decided in a church vote to strengthen the traditionalist position. However, in practice, churches, districts, and conferences within the denomination have, through the years, experienced the freedom to take different positions on controversial or social justice issues (Hill 2019; Zauzmer 2017). In fact, a number of UMC churches have LGBTQ+ ministers and members in leadership and call themselves Reconciling congregations. The anticipation was that the denomination would adopt either a reconciling perspective or one that provides for individual congregations to make their own discernment decision about whether they 
will be Traditionalist or Reconciling. The majority vote at the end of discernment was for a more rigorous traditionalist position, particularly around gay marriage, resulting in disenfranchisement of many progressive churches and members. The denomination continues to work on what that will mean, including the possibility that the Traditionalists will split from the denomination to form a new denominational group (Anderson 2020). That decision indicates that congregations with members and/or clergy who have differing positions about this issue will need to decide with which Methodist denomination they will affiliate, requiring a new layer of process.

\subsubsection{Presbyterian}

Similarly, there were disagreements in the Presbyterian denomination over slavery, abolition, and the Civil War with the dividing line becoming allegiance to "Christ or Caesar (i.e., nation) (Tisby 2019, p. 79). The denomination split in the 1800 s into several groups including the Cumberland Church, the United Presbyterian Church of North America, and what became the Presbyterian Church in the United States (Presbyterian Historical Society 2020). In 2014, the denomination recognized same-gender marriage and placed responsibility for decisions in the local congregation (Presbyterian Mission 2020). Presbyterian Church-USA (PCUSA) includes a group, More Light Presbyterians, who have led advocacy within the church for LGBTQ+ inclusion. In 2018, the PCUSA voted in favor of proposals, called overtures, that included "affirming and celebrating the full dignity and humanity of people of all gender identities" (Presbyterian Mission 2020; Stahl 2018, para. 4) and apologizing for holding a previous unwelcoming stance toward LGBTQ+ parishioners with a position to: "welcome, lift up and fight for the human rights of all people created in the eyes of God" (para. 5). The experience of LGBTQ+ persons in the PCUSA varies depending on the congregation. The organizational structure of the denomination clarifies that the hierarchy moves from the session in the local church to the Presbytery, the Synod, and the General Assembly which is the level at which the 2018 vote took place. That allows the Session and leaders to make decisions for the local church about how those positions shall be lived out locally (Levy 2014; Walmsley 2014).

Rogers (2009) called the controversy centered in attitudes about LGBTQ+ persons the "defining issues of our time" (p. xvii) with parallel personal and denominational journeys of belief leading to an uneasy tension in the denomination.

\subsection{The Church and Change-KAIROS}

Within each of the broader church groups of Baptist, Methodist, and Presbyterian, the denominations and congregations continue to differentiate positionally about LGBTQ+ inclusion. The Association of Welcoming and Affirming Baptists (AWAB) grew out of American Baptists Concerned (ABConcerned). American Baptist Churches (ABC) merged with AWAB in 2004 and developed a role giving voice to LGBTQ+ Baptists (Polaski et al. 2013). These organizations stand in contrast to Baptist groups including the Southern Baptist Convention, whose official position includes identification of "homosexuality" as sin and inconsistent or incompatible with identification as a Christian (Harris and Yancey 2021). In Methodist life, some churches identify themselves as Reconciling Churches with full membership and inclusion of LGBTQ+ persons, while other Methodist congregations identify as "traditional" and do not recognize LGBTQ+ persons as leaders or clergy within the congregation (McConkey 2018). The Presbyterian denomination "locates most responsibility in groups of representative Christians, including both elders (laity) and ministers of the Word (clergy)" (Angell 1984). Angell asserts that each member is responsible for working out answers in understanding with Jesus Christ. This approach provides freedom for individual believers around issues like LGBTQ+ inclusion.

Each denomination includes congregations at various stages of discernment. These denominations and congregations offer insight into the complexities of discernment and strengths and limitations of various processes, decisions, and change. The question of 
formal and informal process is at least partly addressed by the growth in civil conversation and discernment models.

In response to the increase in complex social issues and polarization both in culture and in congregations, there is a growing need for processes to address difference in ways that do not further alienate leaders and members over disagreements. The fracturing that occurs in families and in congregations over LGBTQ+ inclusion in Christianity calls for promising practices to evaluate and find answers that make space for difference while preserving relationships. While there is a plethora of models in the current literature (Gushee 2017; Stains 2016; The Arbinger Institute 2015), the question remains which processes and models are best practices for discussions that lead to decisions without division.

\subsection{Models in the Literature}

While the current climate of polarization and incivility is increasingly acknowledged in the United States (US) and perhaps across other countries and cultures, it was important to understand what resources might be available to congregations and their leaders who were contemplating a discernment process specifically to address the question of LGBTQ+ inclusion. These might well influence the thinking, planning, and processes of congregations both in their discussions and in their decisions. Understanding the cultural context of civil and discernment conversations began with examining the available literature. The authors have published an extensive discussion of the literature (Harris and Yancey 2021). Provided here is a brief overview of the scope of the literature which includes general, business, academic, and religiously-based books and articles.

Leadership and self-help literature include a number of contemporary books on civil discourse with a variety of titles: Braving the Wilderness (Brown 2017); I Beg to Differ (Muehlhoff 2014); Crucial Conversations (Patterson et al. 2012); Nonviolent Communication (Rosenberg 2015); and Difficult Conversations (Stone et al. 1999). Discernment conversation models for churches include books with individual and congregation stories. Examples include Congregations Talking about Homosexuality (Gaede 1998), Behavioral Covenants in Congregations (Rendle 1999), People of a Compassionate God (Fishburn 2003), Rightly Dividing the Word of Truth (Polaski et al. 2013), Changing our Mind (Gushee 2017), and Talking Across the Divide (Lee 2018). Some models are specific to church processes in particular denominations. Examples include Jesus, the Bible, and Homosexuality (Rogers 2009), What Does It Mean to Be Affirming (Collins 2018), Why Churches Need to Talk about Sexuality (Wingfield 2019), and Conservative Christianity, Gender Identity, and Religious Liberty (de Jong 2020). These examples of processes and models are described in more detail "The Why and How of Congregational Discernment in LGBTQ+ Inclusion: Models in the Literature" (Harris and Yancey 2021).

\section{Materials and Methods}

This qualitative research study included a phenomenological approach to explore the experiences of ministers, leaders, and congregants in three denominations as participants discussed engagement of LGBTQ+ persons as members, leaders, and congregants in church sacraments like marriage, baptism, and dedication/baptism of children. The research questions specifically addressed church processes, the issues experienced by congregations, and the lessons learned and recommendations from the congregations. The research question addressed by this article was: "What were the congregational and denominational processes for difficulty conversations and decisions with specific reference to LGBTQ issues?" Baylor University Institutional Review Board found the research "Exempt" from human subject concerns or stipulations.

This article reports on research with 21 congregations in three major Christian denominations to explore processes and lessons learned or suggestions that worked from the participants for other churches to consider. We examine common themes of success and those of challenge in the 21 congregations. We explore evidence of strengths and limitations of model elements in the congregations. The qualitative study explored the experiences of 
96 persons in 21 congregations across Baptist, Methodist, and Presbyterian churches. Participants shared their involvement in formal and informal processes in their congregations to discuss the involvement and inclusion of LGBTQ+ persons in membership, leadership, and church sacrament including marriage. Several resources were written by pastors/leaders of the congregations reporting on their processes, including their experience of promising practices that worked for them.

\subsection{Sample and Consent}

To include a range of responses, the team included three Christian Protestant denominations which vary in their organizational and policy making structures: Baptist, Methodist, and Presbyterian. The research team used a convenience sample method followed by snowball sampling to recruit at least five congregations from each of the three denominations. The majority of the team members had been affiliated with Baptist churches, impacting the convenience sampling. The team was able to successfully recruit 12 Southern and Cooperative Baptist denominational congregations, 5 United Methodist congregations, and 4 Presbyterian congregations. Congregations included those who (1) decided not to have a process and (2) engaged in a process that resulted in a decision along the continuum of traditional to welcoming/affirming/reconciling. The team interviewed a minimum of five persons in all but one congregation; each congregation included at least one minister, one lay leader, and one congregant not in leadership in interviews. Participants were also asked to complete a de-identified demographic form to allow the interview focus to be on more substantive questions. Informed consent forms and demographic forms were emailed to participants, and verbal informed consent was provided and recorded in the interview. Demographic forms were included in the database for analysis with interview transcripts.

\subsection{Interview Process}

The research team invited participation through phone contacts and email contacts with the pastoral leadership, who provided names and contact information for potential interviewees in each category. A member of the team contacted each potential participant, reviewed the oral informed consent, requested completion of a demographics form, and scheduled an interview. Interviews were conducted by phone, video conferencing session, or in person based on availability and participant preference. Interviews were transcribed and then analyzed with demographic forms by the research team using NVivo (QSR International, Burlington, MA, USA), a software for qualitative analysis. Two to three researchers completed free coding on each interview; the coding was analyzed in NVivo by the program manager for interrater reliability. As potential themes were identified, the team met weekly and discussed findings as possible themes and subthemes, agreed on names and definitions, and continued coding until all 97 interviews had been coded by at least two researchers. The language of NVivo included identification of parent nodes, sub-nodes (called children nodes), and a third layer of nodes (called grandchildren nodes). Each was added to the codebook when team agreement was reached on name and definition. When additional research assistants were added in a subsequent academic year, the team revisited the codes as new research assistants continued data analysis. Following the coding, the team identified major themes by the central concept of quotes and the similarities and differences in interviewee responses. Three members of the research team examined quotes in the common nodes and discussed and identified representative quotes that spoke to the theme. Notably, quotes were drawn from all of the 21 congregations and from 64 of the 97 interviews. Quotes represented all categories of interviewees with the majority from ministers and leaders and 21 percent from congregants.

\section{Results}

The research included interviews with ministers, leaders, and congregants of 21 congregations across 3 distinct denominations, i.e., Methodist, Presbyterian, and Baptist. It became apparent early in the analysis that the similarities and differences in the discern- 
ment processes and experiences were not specific to denominations but varied across denominations. Each denomination included congregations with different process variables, with single or multiple processes, and with decisions consistent with their unique church rather than denominational identity. The results provide an overview of the broad categories of processes and of lessons learned. The analysis of the 97 interview transcripts focused on process-related findings.

\subsection{LGBTQ+ Inclusion Conversations}

During the first 18 months of the congregational discernment research project, the team identified churches in each of the three denominations who were having informal and/or formal conversations about LGBTQ+ inclusion, i.e., membership, leadership, and participation in sacraments including marriage, and were interested in sharing their story. The team completed 97 interviews across 21 congregations in 3 denominations that met criteria of attendance, membership, and leadership of LGBTQ+ persons. In this qualitative study, the majority of congregations had engaged in at least one formal process; several had engaged in two or more over a period of years, particularly as new questions or situations emerged. Most frequently in our sample, recent additional process was in response to the SCOTUS decision supporting the legality of same sex marriage. Quotes are identified with the research ID number which are not identified in the references to preserve privacy and confidentiality of the participants.

\subsection{Use of Models}

Despite 30-40 years of some churches wrestling with LGBTQ+ inclusion and leadership (Gaede 1998; Polaski et al. 2013) and the plethora of civil conversation models in the literature (Muehlhoff 2014; Patterson et al. 2012; Rosenberg 2015; Stone et al. 1999), there was not a consensus on model variables for discernment processes in these congregations. While many of the congregations engaged in intentional conversations, there was no pattern on leadership, time frames, or elements like speakers or readings that consistently were part of processes or models. Processes occurred in periods of time ranging from a few meetings to a few months to several years. Leadership of the process ranged from ministers to deacons/elders to lay leaders elected by the church. In some cases, the pastor or ministerial staff were central both to the process and the decision. In other cases, the pastor or ministerial staff took an advisory role, particularly about theological matters such as the understanding of scripture. Some congregations developed an intentional process which they followed, while others allowed the process to emerge over time. The one constant across the 21 congregations, including those who decided not to have a formal process, was that congregations experienced differences of perspectives and even conflict. Notably, several of the ministers in the study wrote books after their process, describing the model used by the congregation in their discernment process.

\subsubsection{Pre-Process}

Identifying the official beginning of discernment conversations was a challenge for some. For many of the 21 congregations, there were multiple conversations, sometimes over a period of years and even decades. Those conversations included formal and informal leadership discussions about the risks and benefits of bringing the discussion into the open, similar to other social justice conversations in the past. Some decisions not to have a process were fear-related, while others found it unnecessary, as reflected in comments such as: "I think there was anxiety about what was going to happen because we knew there were people who opposed it and different levels of people who opposed" (C1B2). Others said: "And then there was the old guard that says 'Well, our mission statement and our vision statement right now says all people. So isn't that enough. Aren't we kind of already saying that, but not quite blatantly?'" (G1C1).

We are a church where we say all are welcome and we really mean that and we believe that. We haven't had any official discernment conversations specific to 
LGBT but we have LGBT people who are members and are involved in almost every area of leadership within the church. Most are not out. (H5A1)

In some congregations, the decision to have a process was begun by leadership and then brought to the congregation over a several year process.

We began talking about how to talk about it. We took it to the deacon body for about a year, with the staff. We studied scripture and read articles. And then decided to bring it to the church body through a weekly Wednesday night discipleship study. (C2A2)

Some engaged in conversations over many years: "We have been through a number of different processes and events over the years-the last 10-12 years" (H3B3). For several churches, there was an unspoken understanding until there was an event that forced an official declaration: "I don't think we've ever said anything certainly during the first 20 years that I was there. It was just, 'Oh, people are accepted. That's fine'" (H6C1V).

Conversations were initiated most frequently by ministers who included the deacons or leadership council in the church. In some cases, the minister responded to expressed concerns by congregants; in others, the minister experienced an internal unction to explore the position of congregants. "At the beginning our pastor wanted to work with our deacons so they spent about six months working on that process" (C2C1M). Pre-process discussions often centered on whether to have a conversation or not and if so, what the process would include. For some churches, the pre-process included a task force, church survey, and development of steps in the process. "We formed a task force to figure out how to guide the way and tried to include demographics across the congregation" (C1A1).

In some cases, the leadership conversation centered around a specific need.

We really needed to have a conversation around what it means to be more welcoming to the trans community. We certainly have trans members, and we just want to start thinking about things like what language do we need to be using or not using? What are ways that we are more visually welcoming, so people know that it's a safe space. So that conversation happened in the deacons. The deacons took it to leadership council. So we had a trans speaker come and talk to us and shared his story. (C3A1)

Many participants reported that the precipitating event for a formal discussion was the decision of the Supreme Court of the United States (SCOTUS) to legalize marriage of same sex couples. "The Supreme Court had its ruling about gay marriage and our pastor couldn't say that it isn't legal in the State of Texas" (H3C1). Another said: "Then the Supreme Court made a decision legalizing gay marriage in all states and so churches were left to kind of scramble" (M5A1).

One frequent impact of the court decision was a new or growing awareness that there were LGBTQ+ persons in the congregation for years without open acknowledgement or recognition. "We all knew we had a growing LGBTQ+ population in our church ... I want to be able to pastor our people honestly and say this is who we are and this is the fulfillment of what you can be here" (M1A1). One participant reported thinking that they did not know anyone who was LGBTQ+ ...

Until I realized that I had been sitting next to and helping bring up a child who now calls herself a lesbian. I have loved this child since she came out of the womb and to say that I don't accept homosexuality is excruciatingly painful to think of how I have been. (H6C1V)

Others' discernment processes were prompted by denominational decisions and the impact of those on individual congregations. One Presbyterian USA participant discussed the need for a congregational conversation after the General Assembly decision for inclusion followed by the Presbytery's decision that congregations make their own determinations. 
In this case, they gave to congregations the choice about whether or not they wanted to host those kinds of services. So we have a saying that people in the local church like to talk about the presbytery or the general assembly as "them" but the reality is they are "us". (M5B3M)

United Methodist Church participants observed that the decision to strengthen the traditionalist position meant those churches which had LGBTQ+ clergy and members had a decision to make.

Our Book of Discipline states right now that the LGBTQ community is not acceptable to Christ's teaching .... So we had a special general conference in which we were going to decide, "Are we going to continue what the Book of Discipline sad or are we going to try and rewrite what the Book of Discipline said?". (H7A1MH)

It is worth considering that the precipitating event for the conversation likely impacted the formality of the process. It also may have driven the leadership structure of the process, guiding the decisions about who would be engaged, what topics of conversations would be included, etc.

\subsubsection{During Process}

Most participants in churches with a formal process reported the inclusion of common process elements: speakers, readings, discussions of scripture, and guided small group conversations (roundtables). "We had a series of Wednesday night discussions that were led by various speakers from the community and the church" (C2C1M).

The variable most often mentioned as essential to a successful process was that of transparency. Many participants noted that it was essential that the leadership selection, process element decisions, and discussions needed to be open and accessible to everyone in the congregation. The opportunity to participate fully and be heard was essential, as was the need for a process that was created and lived out openly.

But I think you really have to be very intentional and work very hard at sort of strengthening the bonds of fellowship within your congregation, creating an atmosphere where people can feel free to express themselves fully, on whatever side of the issue they're on personally. And I think you have to be willing to make space for that to happen and a place and time for that to happen. (C2B2MH)

Transparency also had to do with integrity, i.e., being open about church membership and leadership. Many participants discussed their awareness of LGBTQ persons in the congregation over a period of years without the church acknowledging it.

So we have a deacon in our church ... he's probably 70 now. Born into the church and grew up in the church. He came out probably when he was 30. I think everybody knew he was gay. He was there all the time and was ordained probably before he came out of the closet. We slowly came to terms by watching individuals we know, and loved, realizing about their lives. It didn't change who they were. They were still the people we knew when they were 12 or 18 or whatever. (G1C1)

The presence of LGBTQ+ persons in congregations becomes broader when families in the church are involved. Examples include parents with adolescent and young adult children who grow up in the church and at some point identify as LGBTQ+.

I think people realized how much that issue touched not only people who were already part of our congregation, but families within our congregation who either had friends, family members, etc. who would fit into one of those categories. Many people in our congregation were already dealing with these issues, either within their own family or within friendships. (C2B2MH) 
We had some lesbian couples that visited our church. We have some young men that have grown up in this church that many people have known since the day they were born who had come out fairly recently ... Putting those faces and those families to this issue, I think certainly precipitated us to forge ahead. (C2A2)

Key to the process was providing opportunity for congregants to share their stories and hear the stories of others in the church. Additionally, the story of the church through the years was important to the process. "Honestly, people told their stories. They told stories of their children. They told stories of gays in this congregation" (C2A1). Those stories of church members changed the conversation from issue to persons.

So I think the thing that changed everything for me was preaching the funeral of a gay man who committed suicide whose parents never accepted him. His parents were beautiful people and deep. They have deep faith and they didn't accept their son because of what they had been taught by the church for most of their lives. And when I preached his funeral, I've never felt the judgment of God upon the church more than I did at that moment. (M5A1)

The stories impacted both the church body and the leadership. "Several youth group members came out as gay or lesbian or transgender in the prior couple of years, to the pastor or others ..." (H1B2).

Hearing the stories and how hurt you can be wanting to go to church. It's God's church. It's not my church. And people not wanting you there. I mean, it just broke your heart to listen to these stories. And these are just good Christian churches, so we think. (G1C1)

In some cases, the conversation in a congregation was in response to denominational processes and decisions.

Our presbytery was due to vote on changing the Book of Order that spring so we engaged three town hall meetings, facilitated by a professional mediator elders and deacons were present and between 50 and 85 members chose to participate we had town meetings and then voted on the denominational language. There was a mantra in the church: "If our hearts are one in Christ, our minds don't have to be." (G2A1)

\subsubsection{Process Elements}

The majority of congregational discernment processes began with the leadership of the church, including the pastor/minister(s) and either the leadership team and/or the deacons or elders. Those leaders often designed the process and led it. In some cases, the church leaders appointed or elected a study team to guide the process. The most common elements of the discernment process included discussion of scripture; reading books and articles from multiple perspectives; guest speakers including those from the LGBTQ+ community and including professionals such as physicians, geneticists, teachers, and representatives from other congregations' leadership; and small group discussions like discipleship groups, Sunday School classes, or roundtables. With all of those variables, there were two consistent messages. The first message is that the stories of people can be truly heard. The second is that it is essential that everyone who is willing to participate has the opportunity to be heard. Both are represented in this comment. "I think that providing space to listen and share is important. I believe in the transformative power of personal storytelling, and churches need to make space for that because that is where we see God in people's lives" (H1B2).

\subsubsection{Process Decision}

The process of most congregations included a formal decision, often a vote. In many cases, the vote was on a diversity statement crafted by the group leading the process. "The action team wrote up the diversity statement and that was the thing we were voting on ... 
it was not just LGBT in the diversity statement . . . but they also put in there that we do not discriminate upon marital status" (G1B1).

Maybe I'm oversimplifying a little, but once all the noise died down, people realized that's all we were really deciding on at that point. They were able to say, "Okay, I got that off my chest and I guess it's not all that big of an issue for us anymore". (M5B4M)

We could have used the collective feedback as a vote in some way ... It was, I think, a win for us and our own history. The biggest win was for the congregation as a whole to maintain what was ultimately a loving way to engage disagreement.(M1A3)

\subsubsection{Post-Process}

The end of the process was in most cases a decision which then needed to be implemented. That meant sharing the decision with the church body, often through announcement, church bulletin or newsletter, and the crafting of a statement.

We worked together to come up with a statement... something that the whole deacon body could agree on ... and then it went to the church as a whole in a quarterly business meeting. And that's the statement that is now on our church website .... (C2B2MH)

While many participants reported some loss of membership (i.e., those who disagreed with the decision or did not feel heard in the process), there were also positive outcomes.

We were always going to enjoy each other's company but the difference is now that they know who they're sitting next to and know each other on a more personal level now. We still leave politics at the door, but we don't leave our core convictions at the door the way we used to and we get along beautifully. (G2B2)

For some, the vote concluded their process, and for others, the conversation continued to include additional advocacy work. "You know, I'm so tired of being the red light hanging at the back of the caboose. Can we for one time be the searchlight on the engine?" (G4A2). For some members who disagreed with the decision or vote, the next step was to find another church to live consistent with their own convictions about LGBTQ+ inclusion.

\subsection{Lessons Learned}

The primary lesson learned was that as difficult and painful as the process can be, it was worth it. The difficulty and pain were already there in the church ... in the youth who grew up and hid who they were and eventually left the church or their faith ... in the parents and family members ... in the unspoken differences. So, one lesson repeated often was, have the conversation and make the decision as a church and then live into it.

These are people's lives and it is easy for us to have conversations about the issue and how it affects our churches and denominations and schools and all of the above, but - at the end of the day-these are the people who are beloved children of God. (H5A1)

Participants talked about the challenges and difficulties as contributing to their own growth and the growth of the church. "I'm fascinated to hear these very personal stories of how much our deacons love people in their lives ... whether it is family or friends, neighbors, you know ... and how their lives were changed through that personal connection" (C2C1M). Additionally, about the church ...

Ultimately, it worked itself out and the church did move forward with that and those that were upset by it just found elsewhere to worship ... it did damage, but I think it made us-in the long run- a stronger congregation, refinement by fire .... (H3B3) 
"There's church clarity now and there's all these other things that we will talk about the need for this to happen so LGBTQ+ folks don't get hurt. I think-so they should be reason enough to do it" (M1A4). And finally: "Just have the discussion. I would say every church should at least have it no matter where they end up on it. They should have the discussion and then have it be whatever it is" (G1B1).

\section{Discussion}

These findings of this study were evident across congregations whose conversations ended in not having a formal process, those who had a formal process resulting in a decision, and those whose processes were revisited several times for additional policy changes. Themes that emerged included the evidence that congregations developed their own processes rather than following a specific model from the literature. Those processes included some common elements, but the commitment of the congregations was clearly to their own innovations and tailored processes. A number of congregations had pre-process conversations in which they discussed the risks and benefits of having a discernment process. In many cases, the discernment process resulted in decisions that led to additional conversations motivated by response to LGBTQ+ members and leaders. Other findings included common and unique process elements, decisions, and post-process impacts. A compelling finding was that of lessons learned that can provide guidance for other congregations.

Several things were clear across the 97 interviews. First was that the questions and processes were difficult and painful and resulted in some wounds. Equally important was that as difficult and painful as it can be, having the conversation and making a community decision and living with the decision is worth it. Partly, that was true because the difficulty and pain were already present in these congregations. The "don't ask, don't tell" policy protects the majority from having to acknowledge and deal with pain. It does nothing to protect the hidden population from implied shame and clear not belonging. A number of participants mentioned youth in the church who had grown up and learned to hide who they are while wondering if they were really seen and whether they would be rejected. Those who left the church, and in some cases their families, were on the minds of parents, leaders, and congregants who spoke with us.

The Jewish and Christian scriptures show God as one who sees those on the outside, those on the margins who must hide. Hagar flees abuse from Abraham and Sarah; when God meets her in the wilderness, she recognizes the God who sees (Genesis 16). Incarnate God, Jesus, saw those ignored or hidden from society, saw a wounded man and asked if he wanted to be healed. That question, response, and healing may be a metaphor for the church and the question: "Do you want to be healed?" (John 5). In Matthew 9, Jesus responded to a touch and healed a woman isolated for 12 years with a disease of bleeding. It is not new for God to see the hidden and unseen. The voices of participants in these congregations point out the recognition of those once hidden.

In many cases, the processes resulted in decisions expressed as recognition and belonging. "The decision was 'if you are a member here, there is one class of membership. Every member is entitled to all the same privileges and duties and obligations and rights of every other member, period"" (H1B5). Another participant said it this way: "You are welcome. You are a child of God. God loves you just the way you are" (C2C1M).

\section{Strengths and Limitations}

Some features of the methodology represent both strengths and limitations of the research. Three denominations with varying church and policy-making structures provided the range of both "top down" hierarchy to the Baptist concept of autonomy of the local church. Even so, there are countless iterations of these concepts across multiple denominations which are not explored here. Most important, this research is limited to three Christian denominations and does not include other faith traditions. An important next step is to examine these questions in other major faith traditions including Judaism, 
Islam, and others. Further, while the inclusion of 97 interviews speaks to the strength of multiple points of view from ministers to lay leaders to members outside of leadership structures, the wide range of leadership models makes some aspects of each congregation's process unique to them and more challenging to generalize.

The strength of this study is in the scope. A total of 21 congregations and 97 interviews provided a breadth and depth of information that has not been available to researchers interested in congregational discernment around LGBTQ+ inclusion. Interviews were completed by a team of five researchers and analysis was completed by a team of eleven researchers over several academic years. Participants included ministers, lay leaders, and congregants. These perspectives allowed identification of both similarities and differences of roles and experiences. The denominational perspectives were evident in responses as well.

The scope and breadth of the research is a limitation as well as a strength. Identifying themes was less challenging than identifying the best, most cogent quotes out of the plethora of examples available. The team provided representative quotes from all 21 congregations and from the categories of participants. Another limitation was the absence of demographic information identifying gender, sexual orientation, gender identity, race, and ethnicity. The decision not to gather these data was intentional to encourage participation and reduce concerns about exclusion.

\section{Conclusions}

This question of LGBTQ+ inclusion in Christian congregations is one of the more divisive discussions in the current era. The findings here do not explain directly why this discussion is so difficult for the church. They do, however, clarify that stigma and silence have contributed to the division while the conversations in congregations have elevated the impact of awareness and hearing the stories of LGBTQ+ Christians. Further, the visibility of LGBTQ+ members and of their family members and friends in congregations has made the conversation increasingly important.

Further, this conversation connects in important ways to other social justice issues in the history of the church and of the culture. The history of Christianity is replete with questions of inclusion from the beginning. Historically, the church and her leaders have responded to those questions with examination of scripture and of the impacts of policy on membership, leadership, and participation. The result of differences in understandings, beliefs, and practices includes splits and divisions leading to additional denominations. One notable example in recent history is that of slavery and the Civil War. Many denominations in the United States split over that issue. While the question of slavery has been resolved, race relations continue to generate division and pain in the United States and the world, including in the Christian church. These findings suggest that while some congregations are deciding on full inclusion (affirmation/welcoming/reconciling), the challenges and discussions continue to generate additional discernment processes.

The complexities of LGBTQ+ membership, leadership, and marriage were further impacted by the assortment of options and variables around processes and models. Every congregation is different and has its own identity and history. Those histories and identities served both as motivators and pathways for discernment. The processes for discernment and conversation are varied and must be in order to serve the individuality of communities and their constituents. That is true along the organizational continuum from denomination to congregation.

In the past 40-50 years, the question of LGBTQ+ inclusion has become acknowledged and often contentious. As the culture changes and persons who identify as LGBTQ+ and as Christian are increasingly visible and vocal, denominations and congregations find themselves struggling to establish inclusionary policies and practices. Some have split or fractured over this question. Others have changed and adapted their policies to that change. Still others continue to discuss and discern best responses for the congregation in response to denominational positions. 
In a study of 21 congregations in Baptist, Methodist, and Presbyterian denominations, 97 participants discussed their experience with discernment processes about LGBTQ+ inclusion. The pain of hidden and hurting members is often replaced with the pain and adjustment of disagreement and, in some cases, with members leaving a church deciding to be inclusive or deciding not to be inclusive. Overwhelmingly, participants reported the importance of having an intentional process in which everyone's voice is heard. Most significantly, participants recommended transparency, focusing on the stories of individuals and families, and living with decisions at the pace best for the congregation. While processes varied from short to long, formal to informal, and across outcomes, there was general consensus that having a process is important. Remaining consistent with the identity of the church and seeing this discussion as consistent with other social justice issues were both strong experiences.

These views came from ministers, leaders, and congregants across the spectrum of adulthood. The opportunity seems to outweigh the challenge, and the impact of lessons learned is one of growth and benefit. Congregations and their leaders and members can find in these narratives the opportunity for change, which never comes easy. In this case, participants reported that change comes with significant growth benefit; that was true regardless of the decision of the church. The overarching message from most participants was that, while the process is difficult and often painful, it is important and worth it. Participants recommended that congregations have a discernment process or conversation. That was true whether the decision of the church was to change their position with respect to LGBTQ+ inclusion or not. In both cases, the process provided light on the situation and brought LGBTQ+ persons in the church out of shadows and into the awareness of church members. Living in the shadows brings its own pain and disenfranchisement and deprives the congregation of knowing the fullness of who those members are. Further, it deprives those members of being known for who they are. While that may come with risk, the research results are clear that in most cases, the risk is worth it, irrespective of the decision the congregation makes.

Participants were clear that while there was pain in the losses of congregants who felt they could not stay in the church that made a decision different than their own about inclusion, there was a clear wish for continued relationship. Further, the awareness that other congregations and denominations have different positions and policies about a number of issues did not mean that one was better than another. Participants recognized that the larger umbrella of the denominations in some cases provided space for differences in congregations, and that might one day extend to additional denominations. The processes, while sometimes leading to losses of members in a congregation, still provided hope that the unity of the larger church body is stronger than the divisions.

Author Contributions: H.H. provided conceptualization, literature review / resources, methodology, funding acquisition, investigation, data analysis, writing original draft preparation, and project administration. G.I.Y. provided conceptualization, methodology, funding acquisition, validation, investigation, analysis, project administration, and writing review and editing. K.D. provided literature review/resources, data analysis, validation, and editing. J.G. provided literature review/resources, data analysis, validation, and editing. All authors have read and agreed to the published version of the manuscript.

Funding: This research was funded by the Baugh Foundation.

Institutional Review Board Statement: This research was reviewed by The Baylor University Institutional Review Board, Reference number 1247934 and found to be exempt according to federal regulation 45 CFR 46.101(b). The study was conducted according to the guidelines of the Declaration of Helsinki, and approved by the Institutional Review Board of Baylor University in May 2018 and obtained continued exemption approval in May 2020, Reference number 1247934 and found to be exempt according to federal regulation 45 CFR 46.101(b).

Informed Consent Statement: Informed consent was obtained from all subjects involved in the study.

Data Availability Statement: The data presented in this study are available on request from the corresponding author. The data are not publicly available due to the privacy of congregations and participants which might be identified by those knowledgeable about the congregations. 
Acknowledgments: Support for this article was provided by Carolyn Cole, researcher, Mallory Herridge, project manager, and Geneece Goertzen, research assistant. Thank you to the graduate student assistants over several years who participated in literature review and data collection.

Conflicts of Interest: The authors declare no conflict of interest. The funders had no role in the design of the study; in the collection, analyses, or interpretation of data; in the writing of the manuscript, or in the decision to publish the results.

\section{References}

Allen, Bob. 2019. SBC Resolution Challenges Christians Who Self-Identify as Gay. Baptist News Global. June 14. Available online: https:/ / baptistnews.com/article/sbc-resolution-challenges-christians-who-self-identify-as-gay/\#.X-dlcS9h2fU (accessed on 26 December 2020).

Anderson, Meg. 2020. United Methodist Church Announces Proposal to Split Over Gay Marriage. Available online: https:// www.npr.org/2020/01/04/793614135/united-methodist-church-announces-proposal-to-split-over-gay-marriage (accessed on 4 January 2020).

Angell, James W. 1984. How to Spell Presbyterian. Revised ed. Philadelphia: The Geneva Press.

Baker, Robert A. 2020. Southern Baptist Beginnings. Baptist History and Heritage Society. Available online: http://www.baptisthistory. org/baptistorigins/southernbaptistbeginnings.html (accessed on 15 October 2020).

Baldock, Kathy. 2014. Walking the Bridgeless Canyon: Repairing the Breach between the Church and the LGBT Community. Reno: Canyonwalker Press.

Brown, Brene. 2017. Braving the Wilderness: The Quest for True Belonging and the Courage to Stand Alone. London: Random House.

Chu, Jeff. 2020. A Supreme Court Win for Gay Rights, But Not in My Church. Available online: https://www.nytimes.com/2020/07/ 03/opinion/supreme-court-gay-rights-church.html (accessed on 3 July 2020).

Cole, Carolyn, and Helen Wilson Harris. 2017. The lived experiences of people who identify as LGBT Christians. Social Work $\mathcal{E}$ Christianity 44: 31-52.

Collins, Travis. 2018. What Does It Mean to Be Welcoming? Navigating LGBT Questions in Your Church. Westmont: InterVarsity Press.

de Jong, Dirk H. 2020. Conservative Christianity, Gender Identity, and Religious Liberty: A Primer and a Proposal. London: Palgrove Macmillan.

Duggins, Larry. 2018. Rooted in Grace: Essays on Dialogue without Division. Edited by Andrea L. Lingle Ft. Myers: Columkille Press.

Fishburn, Janet F. 2003. People of a Compassionate God: Creating Welcoming Congregations. Nashville: Abingdon Press.

Gaede, Beth A., ed. 1998. Congregations Talking about Homosexuality: Dialogue on a Difficult Issue. Bethesda: Alban Institute.

Garland, David E., and Diana R. Garland. 2007. Flawed Families of the Bible: How God's Grace Works through Imperfect Relationships. Grand Rapids: Brazos Press.

Gold, Mitchell, ed. 2008. Crisis: 40 Stories Revealing the Personal, Social, and Religious Pain and Trauma of Growing Up Gay in America. Austin: Greenleaf Book Group Press.

Gushee, David. 2017. Changing Our Mind. Canton: Read the Spirits Books.

Harris, Helen, and Gaynor I. Yancey. 2021. The why and how of congregational discernment in LGBTQ+ inclusion: Models in the literature. Religions 12: 14. [CrossRef]

Harris, Helen, Gaynor I. Yancey, Veronica Timbers, and Carolyn Cole. 2020. LGBTQ+ and Christian: Who Decides? Journal of Religion and Spirituality in Social Work 39: 452-73. [CrossRef]

Hill, Craig C. 2019. A Statement from Perkins School of Theology Dean Craig C. Hill. Available online: https://www.smu.edu/ Perkins/News/News_Archives/Archives_2019/2019-Dean-Hill-Statement (accessed on 1 March 2020).

Human Rights Campaign. 2020. Stances of Faiths on LGBTQ Issues: Southern Baptist Convention. Available online: https://www.hrc. $\mathrm{org} /$ resources/stances-of-faiths-on-lgbt-issues-southern-baptist-convention (accessed on 6 November 2020).

Jones, Robert. 2020. White Too Long. New York: Simon \& Schuster.

King, Martin Luther, Jr. n.d. AZQuotes.com. Wind and Fly LTD. Available online: https:/ / www.azquotes.com/quote/933766 (accessed on 26 December 2020).

Lee, Justin. 2018. Talking across the Divide: How to Communicate with People You Disagree with and Maybe Even Change the World. New York: TacherPerigee.

Levy, Denise. 2014. Christian doctrine related to sexual orientation: Current climate and future implications. In Conservative Christian Beliefs and Sexual Orientation in Social Work: Privilege, Oppression, and the Pursuit of Human Rights. Edited by Adrienne. B. Dessel and Rebecca M. Bolen. Alexandria: CSWE Press.

McConkey, Dale. 2018. United Methodists Divided: Understanding Our Differences over Homosexuality. Washington, DC: Global Parish Press.

Muehlhoff, Tim. 2014. I Beg to Differ. Downers Grove: InterVarsity Press.

Patterson, Kerry, Joseph Grenny, Ron McMillan, and Al Switzler. 2012. Crucial Conversations: Tools for Talking When Stakes Are High, 2nd ed. New York: McGraw Hill.

Polaski, Ledayne M., Eiland Millard, and Cody Sanders. 2013. Rightly Dividing the Word of Truth: A Resource for Congregations on Sexual Orientation and Gender Identity. Charlotte: Baptist Place Fellowship of North America. 
Presbyterian Historical Society. 2020. The National Archives of the PC(USA): History of the Church. Available online: https: //www.history.pcusa.org/history-online/presbyterian-history/history-church (accessed on 26 December 2020).

Presbyterian Mission. 2020. Presbyterian Mission Church (USA) Sexuality and Same Gender Relationships. Presbyterian Church (USA). Available online: https://www.presbyterianmission.org/what-we-believe/sexuality-and-same-gender-relationships / (accessed on 13 November 2020).

Rendle, Gilbert R. 1999. Behavioral Covenants in Congregations. Bethesda: The Alban Institute, Inc.

Richards, Lawrence O. 2002. Bible Teacher's Commentary. Colorado Springs: Cook Communications Ministries.

Richards, Jeffrey. 2020. The Splintered Cross: Exploring the Origins of Christian Denominations; A Step toward Understanding One Another. Bountiful: KwestWorks.

Robertson, Brandan. 2017. Our Witness: The Unheard Stories of LGBT+ Christians. London: Darton, Longman + Todd.

Rogers, Jack. 2009. Jesus, the Bible, and Homosexuality: Explode the Myths, Heal the Church. revised ed. Louisville: Westminster John Knox Press.

Rosenberg, Marshall B. 2015. Nonviolent Communication: A Language of Life. Encinitas: Puddle Dancer Press.

SCOTUS. 2014. Supreme Court of the United States (SCOTUS). Obergefell et al., v. Hodges, Director, Ohio Department of Health, et al. Available online: http:/ / apps.washingtonpost.com/g/documents/preview/1605/desktop/?das= (accessed on 15 July 2020).

Shelley, Bruce L. 2013. Church History in Plain Language, 4th ed. Nashville: Thomas Nelson.

Stahl, Shane. 2018. Presbyterian Church Makes History, Adopts Official Pro-LGBTQ Stances at Biennial Conference. Available online: https:/ / www.freedomforallamericans.org/presbyterian-church-makes-history-adopts-official-pro-lgbtq-stances-atbiennial-conference/ (accessed on 13 October 2020).

Stains, Robert R., Jr. 2016. Cultivating courageous communities through the practice and power of dialogue. Mitchell Hamline Law Review 5: 1520-45.

Stone, Douglas, Bruce Patton, and Sheila Heen. 1999. Difficult Conversations: How to Discuss What Matters Most. New York: Penguin Books.

The Arbinger Institute. 2015. The Anatomy of Peace: Resolving the Heart of Conflict, 2nd ed. Oakland: Berrett-Koehler Publishers, Inc.

Tisby, Jemar. 2019. The Color of Compromise. Grand Rapids: Zondervan Books.

Walmsley, Frank. 2014. Handbook for Elders in the Presbyterian Church (USA). revised 3rd ed. Louisville: Westminster John Knox.

Wingfield, Mark. 2019. Why Churches Need to Talk about Sexuality: Lessons Learned from Hard Conversations and Bout Sex, Gender, Identity, and the Bible. Minneapolis: Fortress.

Zauzmer, Julie. 2017. The United Methodist Church has appointed a transgender deacon. The Washington Post. June 6. Available online: https: / www.washingtonpost.com/news/acts-of-faith/wp/2017/06/07/the-united-methodist-church-just-appointeda-transgender-deacon/ (accessed on 15 July 2020).

Zylstra, Sarah Eekhoff. 2016. Southern Baptists Repudiate the Confederate Flag. Christianity Today. June 14. Available online: https: / / www.christianitytoday.com/news/2016/june/southern-baptists-racial-reconciliation-sbc-civilitas-pca.html (accessed on 15 July 2020). 